\title{
IFRS ADOPTION AND EARNINGS MANAGEMENT PRACTICE: EVIDENCE FROM INDONESIA COMPANIES
}

\author{
Vina Kholisa Dinuka \\ * Batam Polytechnics \\ Accounting Study Program \\ Parkway Street, Batam Centre, Batam 29461, Indonesia \\ E-mail: vinakholisa@polibatam.ac.id
}

\begin{abstract}
Abstrak
Tujuan penelitian ini adalah memverifikasi kontribusi IFRS dengan menguji keberadaan manajemen laba akrual (AEM) dan manajemen laba riil (REM) sebelum dan sesudah penerapan IFRS pada perusahaan manufaktur di Indonesia. AEM diukur dengan nilai absolut discretionary accrual, sedangkan REM diproksikan dengan 3 pengukuran REM yaitu abnormal cash flow operation, abnormal production dan abnormal discretionary expenses. Sampel penelitian diambil dari Bursa Efek Indonesia pada periode 2009-2011 dan 2013-2015. Tahun 2012 merupakan periode adopsi IFRS di Indonesia dan dikeluarkan dari sampel penelitian karena dianggap sebagai tahun perpindahan standar. Penelitian ini menggunakan analisis regresi dan Paired t-test untuk membandingkan keberadaan AEM dan REM sebelum dan sesudah adopsi IFRS. Hasil penelitian mengungkapkan bahwa adopsi IFRS mempunya pengaruh signifikan negatif terhadap AEM dan REM. Hal ini menunjukkan bahwa setelah adopsi IFRS, AEM dan REM menurun. Oleh karena itu, IFRS mampu untuk mengurangi praktik manajemen laba baik dalam bentuk AEM maupun REM di perusahaan manufaktur di Indonesia.
\end{abstract}

\section{Kata kunci: IFRS, Manajemen Laba Akrual, Manajemen Laba Riil}

\begin{abstract}
The purpose of this study is to verify IFRS contribution by examining the presence of Accrual Earnings Management (AEM) and Real Earnings Management (REM) in the period pre-and post-IFRS implementation in manufacturing companies in Indonesia. AEM is measured by absolute value of discretionary accrual, while REM is proxied by three measurements of REM, they are abnormal cash flow operation, abnormal production and abnormal discretionary expenses. The sample is taken from Indonesia stock exchange in 2009-2011 and 2013-2015. 2012 is Indonesia adoption period and it is excluded from the sample, because it is considerated as transitory year. This study uses regression analysis and Paired t-test to compare the presence of AEM and REM preceding and following IFRS implementation. The findings reveal that IFRS adoption has significantly negative effect towards AEM and REM. It indicates that the following IFRS implementation, AEM and REM are decrease. Therefore, IFRS is able to reduce earnings management practices in manufacturing companies in Indonesia both for AEM and REM.
\end{abstract}

Keywords: IFRS, Accrual Earnings Management, Real Earnings Management. 


\section{Introduction}

Financial statements are used for explaining financial and non-financial information to parties outside the corporation. These parties use the financial statements to obtain complete and valid information about the company performance. They use this information as a guide for making financial decisions.

Due to the importance of financial statement information, the company's management has to provide a clear, valid and complete financial statement for these different parties outside the company. This financial statement also has to be prepared using international accounting standards to comply with the uniformity element and can be understood by all parties with an interest in the financial statement.

The International accounting standard that can be used as a guide for preparing the financial statement is International Financial Reporting Standards (IFRS). IFRS implements a principle-based standard that is expected can enhance high-quality accounting number. Earnings management level appear in a company can indicate the level of accounting quality, because it shows that management has a flexibility in managing earnings in accordance with the objectives of certain parties [E]. Indonesia has started to implement fully IFRS as a standard in preparing financial statements since 2012.

There is a debate about IFRS's ability to increase the financial statement quality around the world. Some past researchers find that IFRS can upgrade the financial statements quality by restricting the management flexibility in manipulating earnings to achieve the desired outcome $[D ; O ; X]$. However, other researchers still exhibit the evidence that after IFRS adoption, management still have a tendency to manage company's earnings, even they switch the form of earnigs from accrual way into the real one [T; $H ; L]$.

There is still a limited amount of research in Indonesia which verify the presence and level of AEM and REM pre- and post- IFRS implementation. Therefore, this research aims to examine whether first, IFRS adoption can diminish accrual earnings management practice in the manufacturing company in Indonesia, taking into account that IFRS is prepared to improve the financial quality due to the tighter regulations that can limit the earnings management practices. Second, whether after the IFRS adoption, REM practices increase due to the limitation of management's flexibility, thus it is turned into another form of accrual earnings management, namely real earnings management.

\section{Literature Review}

\section{Literature review}

\section{Agency Theory}

This theory explained that there is a working relationship between the parties that gave an authority (principal) is the investor/shareholder with a party that receiving the authority (agency) is the manager in the form of a cooperation contract $[F]$. The segregation of ownership and control right can lead to some serious conflicts of interest between the financial statement users. Information asymmetry also was suspected as a factor that leads the interest dispute among the users of financial statement [A].

\section{IFRS in Indonesia}

Indonesia as a member of G20 countries agreed to adopt IFRS as an international standard in preparing financial statements. Started in 2006-2008, IFRS began to enter Indonesia as an international accounting standards. In that year, Indonesia's old accounting standards began to be revised, beginning with the refinement or addition of new standards. Then, in 2008-2010 is the year of IFRS preparation for Indonesia, starting from infrastructure preparation and standard evaluation that has been set. In 2011, this is the final year of preparation for IFRS implementation. Finally, by 2012, all business players in Indonesia are required to fully implement IFRS as an accounting standard in preparing their company's financial statements [C].

\section{Earnings Management}

[AA] revealed that managing the earning take place when managers utilize their discretion by choosing certain reporting or measuring methods, with the aim to affect the accounting figures to comply their private goals.

[V] also assessed that earnings management is considered not entirely against the rules and principles of acceptable accounting. Yet, earnings management practices can erode investor confidence towards the quality of financial statements as well as disrupt capital flows in the capital market. In addition, earnings management can also reduce earnings reliability due to reported earnings bias and lead to errors in describing actual earnings. Earnings management consists of Accrual-based Earnings Management (AEM) and Real Earnings Management (REM). 


\section{Accrual Earnings Management (AEM)}

Accrual earnings management is performed by manipulating the accrual method that is not directly related to cash flow. Accrual is based on the certain methods and estimation [S]. [X] also added that accrual earnings management can be performed by changing the accounting method used to other alternative accounting methods that are more profitable for management.

The accrual transactions can be tangible as (1) non-discretionary accruals (NDA) transaction and (2) discretionary accruals (DA) transactions. NDA transactions occur when the transaction has been computed using a certain measurement and it is predicted using this measurement permanently. Meanwhile, DA transactions are defined as a method that gives a flexibility to company to determine the amount of the accrual transactions [J].

\section{Real Earnings Management (REM)}

[T] describes REM as another form of earnings management which is done through manipulating the company's operational activities. This manipulation is a deviation from normal business operations to trick some financial statements' users to convince that financial statement's target has been accomplished by normal activities. $[B B]$ grouping the methods to perform real earnings management into three activities. They are manipulation from operating, investing and financing activities.

Nowadays, many researchers concern to reveal the existence of REM in companies. Therefore, the restriction of AEM practices and the widespread disclosure of financial statements, managers are predicted to use real activities to manipulate earnings. [CC] also states that when AEM is restricted, managers prone to perform REM. It means that the limitation to commit accrual-based manipulation can trigger REM practice.

\section{Hypothesis}

IFRS engages fair value measurement, using principal based and require more detailed disclosure compared with previous local accounting standards GAAP where it can limit the manager behavior to perform earnings management practice. Moreover, with full disclosures approach, the users of financial statement are expected can obtain the same information as used as by the manager. Therefore, there is no information asymmetry can initiate earnings management practices [A].

Theoretically, the convergence from local standards to IFRS is considered would mitigate earnings management practice. However, some researchers still find the different results associated with the influence of IFRS adoption towards accrual earnings management. Therefore, the efficiency of IFRS still questionable in this study.

$[R]$ revealed that IFRS implementation leads to the enhancement of quality of accounting information, proved by a lower accrual earnings management practice. $[Y]$ found that adopting a set of international accounting standards can trigger the management to report truthfully and finally leads in fewer earnings management practice. [K] specifically examined the impact of implementation of international accounting standard to limit earnings management practice. The results confirm that the more stringent the accounting standards are applied, the lower the earnings management is performed.

On the contrary, [U] found that IFRS adoption in India leads to increase earnings management. [Q] reviewed the changes of earnings management pattern and stated that IFRS ineffective reduces earnings management practices. In addition, [B] suggest that the IFRS adoption results in smoothing earnings and reporting accrual aggressively in the companies which adopt IFRS.

Based on the previous literatures, although there are still conflicting research findings related to the influence of IFRS adoption to the accrual earnings management, theoretically, IFRS prone to be judged to improve the accounting quality and reduce accrual earnings management practices. Based on the above arguments, this study construct the first hypothesis as follows: 
Hypothesis 1: After the adoption of IFRS, the magnitude of accrual earnings management in Indonesia companies decreases

After the adoption of IFRS, earnings quality is expected increased and accrual earnings management is limited. However, some researchers found that managers still perform earnings management through real activities due to the tighter accounting standards in the period after IFRS adoption. [N] denoted that European firms prone to switch accrual earnings manipulation with real one after IFRS adoption. [L] also documented that REM is increase, while AEM is decrease in the period after IFRS adoption. It implies that the firms turn to shift from AEM to REM.

[W] found the evidence that French firms perform REM and AEM as complementary tools to smooth earnings in the period after the mandatory of IFRS adoption. [S] also revealed the evidences that there was a shift from AEM to REM after the IFRS adoption. Based on the arguments above, therefore this study construct the second hypothesis as follows:

Hypothesis 2: After the adoption of IFRS, the magnitude of real earnings management in Indonesia companies increases

\section{Research Method}

\section{Data Sample}

The sample for this research is manufacturing company that listed in Indonesia Stock Exchange in the preceding and following IFRS implementation. the sample is taken from 2009-2011 and 2013-2015. 2012 is excluded from the research sample, since Indonesia starts to fully adopt IFRS in this year, and 2012 is considered as transitory year. The total sample in this research is 156 manufacturing companies.

\section{Dependent Variable}

The dependent variables in this study are AEM and REM. This study examine the presence of AEM and
REM pre- and post- IFRS implementation in manufacturing companies in Indonesia.

(AEM) is proxied by Discretionary Accrual (DA) with separating them from non-DA using Modified Jones model [M]. Meanwhile, the existence of REM is observed using the methodology initiated by $[P]$. REM is performed in three forms: overproduction sales, exceptionally low (Discretionary Expenses) DISEXP, and sales manipulation that cause in abnormally low (Cash Flow Operation) CFO. The equation for measuring AEM and REM are as follows:

\section{AEM}

AEM is proxied by discretionary accrual (DA) and separating them from non-DA (NDA). The formula (i) is used to measure DA:

$$
\mathrm{TA}_{i t}=\mathrm{NI}_{i t}-\mathrm{CFO}_{i t}
$$

Formula (i)

$T A_{i t}$ is the total accruals of company $i$ at year $t ; N I_{i t}$ is net income of company $i$ at year $t$; $C F O_{i t}$ is the cash flow from operation activities. Therefore, the following regression is examined for each industry and year to compute the coefficient regression:

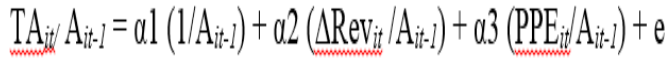

$A_{i t-1}$ is the total assets of company $i$ at year $t-1 ; \Delta$ Rev $_{i t}$ the sales change of company $i$ between $t$ and $t-1$; $P P E_{\text {it }}$ the net value of property, plant and equipment of company $i$ in year $t$. Based on the coefficient regression from equation 1 , the value of NDA is measured below:

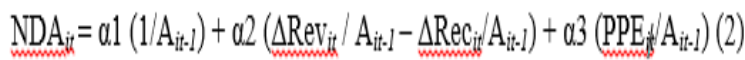

$N D A_{i t}$ is the non-discretionary accrual of company $i$ at $t$. Then, the coefficient regression from equation 1 is also used to compute total accrual in equation 3 below:

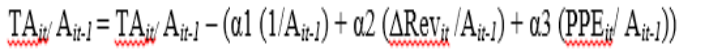


Finally, discretionary accrual (DA) is measured using formula (ii):

$$
\mathrm{DA}_{i t}=\mathrm{TA}_{i t} \mathrm{~A}_{i t-1} \downarrow \mathrm{NDA}_{i t}
$$

Formula (ii)

AEM parctices is computed using the absolute value of discretionary accrual (Abs_DA). Since, this research want to examine the magnitude of AEM not the direction.

\section{REM}

This study estimates real earnings management by measuring abnormally high PROD, abnormally low CFO and DISEXP. The first form of REM is abnormally low CFO. Abnormal CFO is defined as a Sales change and the equation below is computed for each industry and year:

$$
\frac{C F 0_{i, t}}{\text { Assets }_{i, t-1}}=a_{0}+a_{1} \frac{1}{\text { Assets }_{i, t-1}}+a_{2} \frac{\operatorname{Rev}_{i, t}}{\text { Assets }_{i, t-1}}+a_{3} \frac{\Delta \operatorname{Rev}_{i, t}}{\text { Assets }_{i, t-1}}+e_{i, t}
$$

formula (iii)

$\mathrm{CFO}_{\text {it }}$ is the cash flows of company $\mathrm{i}$ from operating activities for year $t$; $\operatorname{Rev}_{i t}$ is the sales of company $i$ at the end of year $t$; and other variable has defined before. The estimated coefficients $\alpha_{0}, \alpha_{1}, \alpha_{2}$, and $\alpha_{3}$ from the equation above is used to measure abnormal CFO:

$\mathrm{Ab}_{-} \mathrm{CFO}_{i, t}=\frac{\mathrm{CFO}_{i, t}}{\text { Assets }_{i, t-1}}-\left[\hat{a}_{0}+\hat{a}_{1} \frac{1}{\text { Assets }_{i, t-1}}+\hat{a}_{2} \frac{\operatorname{Rev}_{i, t}}{\text { Assets }_{i, t-1}}+\hat{a}_{3} \frac{\Delta \operatorname{Rev}_{i, t}}{\text { Assets }_{i, t-1}}\right]$

formula (iv)

The second form of REM is abnormally high PROD. PROD is defined as the summation of Cost of Goods Sold and the inventory change, and are examined by using for each industry and year:

$\frac{P R O D_{i, t}}{\text { Assets }_{i, t-1}}=a_{0}+a_{1} \frac{1}{\text { Assets }_{i, t-1}}+a_{2} \frac{\text { Rev }_{i, t}}{\text { Assets }_{i, t-1}}+a_{3} \frac{\Delta \text { Rev }_{i, t}}{\text { Assets }_{i, t-1}}+a_{4} \frac{\Delta \text { Rev }_{i, t-1}}{\text { Assets }_{i, t-1}}+e_{i, t}$

formula (v)

Using the coefficient $\alpha_{0}, \alpha_{1}, \alpha_{2}, \alpha_{3}$, and $\alpha_{4}$ computed in the equation above, abnormal PROD (Ab_PROD) are measured below:

$$
\begin{aligned}
A b_{-} P R O D_{i, t}= & \frac{\operatorname{PROD}_{i, t}}{\operatorname{Assets}_{i, t-1}}-\left[\hat{a}_{0}+\hat{a}_{1} \frac{1}{\operatorname{Assets}_{i, t-1}}+\hat{a}_{2} \frac{\operatorname{Rev}_{i, t}}{\operatorname{Assets}_{i, t-1}}\right. \\
& \left.+\hat{a}_{3} \frac{\Delta \operatorname{Rev}_{i, t}}{\operatorname{Assets}_{i, t-1}}+\hat{a}_{4} \frac{\Delta \operatorname{Rev}_{i, t-1}}{\operatorname{Asset~}_{i, t-1}}\right]
\end{aligned}
$$

formula (vi)

The last form of REM is abnormally low DISEXP and examined by regression below for each industry and year:

$\frac{\operatorname{DISEXP}_{i, t}}{\text { Assets }_{i, t-1}}=a_{0}+a_{1} \frac{1}{\text { Assets }_{i, t-1}}+a_{2} \frac{\text { Rev }_{i, t}}{\text { Assets }_{i, t-1}}+e_{i, t}$

formula (vii)

DISEXP $P_{i t}$ is the summation of SG\&A expenses (selling, general and administrative) and Research and Development $(R \& D)$ expense at year $t$. After estimating the equation above, the coefficient regression $\alpha_{0}, \alpha_{1}$, and $\alpha_{2}$ are used to compute the abnormal discretionary expenses (Ab_DISEXP) as follows:

$A b_{-} D I S E X P_{i, t}=\frac{\operatorname{DISEXP}_{i, t}}{\text { Assets }_{i, t-1}}-\left[\hat{a}_{0}+\hat{a}_{1} \frac{1}{\text { Assets }_{i, t-1}}+\hat{a}_{2} \frac{\operatorname{Rev}_{i, t}}{\text { Assets }_{i, t-1}}\right]$

formula (viii)

The final step, this study performs a single measurement of REM (RM_PROXY) by merging three REM measurements for Ab_CFO,Ab_DISEXP and $A b \_P R O D$ into one measurement [H]. Formula to measure comprehensive REM (RM_PROXY) is described as follow:

$R M P R O X Y=-A b C F O+A b P R O D-A b$ DISEXP

Formula (ix)

Thus, the higher the value of RM_PROXY, the higher upward REM is expected engaged by company.

\section{Independent Variable}

The independent variable used in this research is the adoption of IFRS. The independent variable uses dummy variable. IFRS variable has the value 1 if the observation refers to year post-IFRS implementation (period 2013-2015) and 0 for year pre-IFRS adoption (period 2009-2011) [I]. 
The further examination is conducted to observe the effect of IFRS implementation on earnings management, both for AEM and REM using regression analysis. The following equations are computed using Ordinary Least Square (OLS) for the sample in the periods before (2009-2011) and after (2013-2015) the IFRS adoption pooled together:

\section{Equation for hypothesis 1:}

Abs_DA $=\beta 0+\beta 1$ LNASSETSit $+\beta 2 L E V i t+\beta 3 B I G i+\beta$ IIFRSt + sit Equation for hypothesis 2:

RM_PROXY $=\beta O+\beta 1 L N A S S E T S i t+\beta 2 L E V i t+\beta 3 B I G i+\beta 4 I F R S t+$ sit

In the first equation model, the regression analysis examine the effect of the adoption IFRS towards AEM proxied by the absolute discretionary accrual. Thus, the dependent variable in the first model is absolute $D A$ and the independent variable is IFRS. In the first equation, the adoption of IFRS is expected has negative effect to the accrual earnings management. Since, IFRS is expected can restrict the management behavior to manipulate earnings through accrual way.

In the second equation model, the regression analysis examine the impact of the adoption IFRS towards REM. REM is proxied using 3 measurements. They are abnormal cash flow operation, abnormal production, and abnormal discretionary expense. These measurements is combinied into a single measurement, namely RM_PROXY. Thus, the dependent variable in the second model is the comprehensive measurement of real earnings management (RM_PROXY) and the independent variable is IFRS. In the second model, the adoption of IFRS is expected has positive effect to the REM. Since, after the IFRS implementation, company's management is predicted switch the earnings management form, from accrual into real activities.

Abs_DA is the absolute value of discretionary accruals (DA) examined under Modified Jones model 1991; RM_PROXY is the comprehensive measurement of REM, three measurement of REM 234 | Jurnal Akuntansi, Ekonomi dan Manajemen Bisnis | Vol. 7 No.2, December 2019, 229-239 | E-ISSN: 2548-9836
(Ab_CFO, Ab_PROD, Ab_DISEXP) are combined into a single measurement RM_PROXY; LNASSETS is the natural logarithm of total assets of company $i$ at year $t$; $L E V_{i t}$ is the leverage of company $i$ in year $t$, defined as total liabilities divided by total assets; $B I G_{i}$ is the dummy variable, when the auditor's company is include following five auditors: Delloite, PWC, KPMG, E\&Y, or Grant Thornton, then the dummy variable is one and zero otherwise; IFRS $S_{t}$ is also the dummy variable that has value 1 if the observation include in the period post-IFRS implementation (period 2013-2015) and zero for the period pre-IFRS implementation (period 2009-2011) [I].

The selection of control variables is based on the previous study $[K]$. Control variables used are company size (LNASSETS), leverage (LEV), and auditor (BIG), which are assumed have the influence towards AEM and REM. [I].

The data sample in this research is manufacturing companies listed in the Indonesia Stock Exchange (BEI) in the three years preceding and following IFRS adoption. This study uses three years period pre-and post- the implementation of IFRS in Indonesia as the research period.

Indonesia starts to fully adopt the international accounting standards in 2012. The preceding period of IFRS adoption are 2009 until 2011, while the following period of the IFRS adoption are 2013 until 2015. 2012 is excluded from the examination period, as this year is the actual year of initial adoption and considered as a transitory year.

\section{Results and Analysis}

\section{Results}

Descriptive Statistics

TABLE 4.1

DESCRIPTIVE STATISTICS

PERIOD BEFORE IFRS ADOPTION

\begin{tabular}{lccccc}
\hline & N & Min & Max & Mean & $\begin{array}{c}\text { Std. } \\
\text { Deviation }\end{array}$ \\
\hline Abs_DA & 156 & 0,002 & 0,706 & 0,163 & 0,115 \\
Ab_CFO & 156 & $-0,545$ & 0,324 & $-0,035$ & 0,129
\end{tabular}




\begin{tabular}{lccccc} 
Ab_PROD & 156 & $-0,791$ & 1,097 & 0,134 & 0,306 \\
Ab_DISEXP & 156 & $-0,375$ & 0,469 & $-0,015$ & 0,149 \\
RM_PROXY & 156 & $-1,405$ & 1,798 & 0,184 & 0,456 \\
LNASSETS & 156 & 18,061 & 25,757 & 21,044 & 1,607 \\
LEV & 156 & 0,074 & 0,892 & 0,443 & 0,196 \\
\hline
\end{tabular}

Source: processed data

Table 4.1 describes the descriptive statistics analysis for the sample data in the period before the IFRS adoption for all variables. Meanwhile, the descriptive statistics analysis for the sample data in the period after the IFRS adoption is displayed below:

TABLE 4.2

DESCRIPTIVE STATISTICS

\begin{tabular}{lccccc}
\hline \multicolumn{6}{c}{ PERIOD AFTER IFRS ADOPTION } \\
\hline Abs_DA & 156 & 0,002 & 0,390 & 0,122 & 0,077 \\
Ab_CFO & 156 & $-0,306$ & 0,344 & $-0,003$ & 0,107 \\
Ab_PROD & 156 & $-0,988$ & 0,725 & $-0,004$ & 0,279 \\
Ab_DISEXP & 156 & $-0,341$ & 0,373 & $-0,017$ & 0,139 \\
RM_PROXY & 156 & $-1,318$ & 1,299 & 0,017 & 0,434 \\
LNASSETS & 156 & 18,712 & 26,226 & 21,625 & 1,704 \\
LEV & 156 & 0,050 & 0,881 & 0,424 & 0,197 \\
\hline
\end{tabular}

Source: processed data

\section{Correlation Matrix}

Correlation matrix is performed to compute the strength and the linier direction relationship of two variables. The variables Abs_DA, Ab_CFO, $A b \_P R O D, A b \_D I S E X P, R M \_P R O X Y$, LNASSETS, $L E V, B I G$, and IFRS are measured by correlation matrix. Table 4.3 presents the correlation matrix analysis for all variables.

TABLE 4.3

CORRELATION MATRIX

$(\mathrm{N}=312)$

\begin{tabular}{|c|c|c|c|c|c|c|c|c|c|}
\hline & Abs_ $D A$ & $\mathrm{Ab}_{-} \mathrm{CFO}$ & Ab_PROD & Ab_DISEXP & RM_PROXY & LNASSETS & LEV & $B \mid G$ & IFRS \\
\hline Abs_DA & 1 & & & & & & & & \\
\hline $\mathrm{Ab}_{-} \mathrm{CFO}$ & 0,009 & 1 & & & & & & & \\
\hline Ab_PROD & $.0,010$ & $-0,451^{\prime-}$ & 1 & & & & & & \\
\hline Ab__lSEXP & $-0,205^{-*}$ & 0,156 & $-0,481^{\cdots \prime}$ & 1 & & & & & \\
\hline RM_PROXY & 0,056 & $-0,614^{*+*}$ & $0,9366^{* \prime \prime}$ & $.0,678^{* \prime \prime}$ & 1 & & & & \\
\hline LNASSETS & $-0,109$ & $-0,031$ & $-0,047$ & $-0,091$ & 0,006 & 1 & & & \\
\hline LEVi,t & 0,073 & $-0,319^{*+*}$ & $0,398^{* *+}$ & $.0,434^{\prime \prime}$ & $0,487^{\prime \prime \prime}$ & 0,080 & 1 & & \\
\hline BIGi,t & $-0,038$ & $0,197^{m *}$ & $-0,332$ & $0,218^{m \prime}$ & $-0,342^{\prime \prime \prime}$ & $0,540 "$ & $-0,187^{\cdots "}$ & 1 & \\
\hline IFRSt & $-0,206^{* \prime \prime}$ & $0,133^{* *}$ & $-0,230^{*+*}$ & $-0,007$ & $-0,1866^{* \prime \prime}$ & $0,173^{m+*}$ & $-0,047$ & $.0,020$ & 1 \\
\hline
\end{tabular}

\section{Paired t-Test}

Paired t-test is applied to examine whether there is an average difference between the two groups of paired samples, in which a sample has a different treatment. The paired t test both for AEM and REM is presented in table 4.4 for period before and after IFRS adoption.

TABLE 4.4

PAIRED T-TEST

AEM AND REM PRE- AND POST- IFRS ADOPTION

\begin{tabular}{|c|c|c|c|c|c|}
\hline \multicolumn{2}{|c|}{$2009-2011$} & \multicolumn{2}{|c|}{$2013-2015$} & \multirow{2}{*}{$\begin{array}{l}\text { Difference between 2009-2011 } \\
\text { and 2013-2015 }\end{array}$} & \multirow{2}{*}{ Sig } \\
\hline & mean & & mean & & \\
\hline Abs, DA & 0,1633 & Abs.DA & 0,1223 & $0,0411^{\text {k*k }}$ & 0,001 \\
\hline $\mathrm{Ab} C \mathrm{CFO}$ & $-0,0351$ & $\mathrm{Ab} C \mathrm{CFO}$ & $-0,0034$ & $-0,0272^{* * *}$ & 0,000 \\
\hline$A b$ PROD & 0,1343 & $A b, P R O D$ & $-0,0039$ & $0,1342^{* k *}$ & 0,000 \\
\hline Ab DISEXP & $-0,0149$ & Ab DISEXP & $-0,0131$ & $0,0042^{* * *}$ & 0,000 \\
\hline RM_PROXY & 0,1843 & RM_PROXY & 0,0166 & $0,1571^{* k *}$ & 0,000 \\
\hline
\end{tabular}

Based on the table 4.4, accrual earnings management proxied by Abs_DA shows mean value 0.1633 in the period before IFRS adoption, then the value is decrease at 0.1223 in the period after the IFRS adoption. It indicates that Abs_DA statistically significant downward after the IFRS adoption by 4.1 percent. Furthermore, real earnings management through abnormal cash flows operation (Ab_CFO) has a downward in the period post-IFRS adoption from -0.0351 to -0.0034 or about 3 percent.

Moreover, the other form of REM, Ab_PROD and $A b \_D I S E X P$ also have a downward real earnings management practice in the following IFRS implementation about 13 and 0.4 percent, respectively. Finally, the comprehensive measurement of REM, RM_PROXY also exhibits a significantly decrease in the mean value after IFRS adoption, from 0.1843 to -0.0166 or about 16 percent. It can be concluded that the implementation of IFRS in Indonesia can limit accrual and real earnings 
management practice in the Indonesia manufacturing companies.

\section{Regression Analysis}

This regression analysis is applied to check the relationship between the independent variable IFRS towards the dependent variable AEM proxied by $A b \_D A$ in the first model and REM in the second regression model.

\section{TABLE 4.5}

REGRESSION ANALYSIS

IFRS AND AEM (FIRST MODEL)

\begin{tabular}{|c|c|c|c|c|}
\hline \multicolumn{5}{|c|}{ 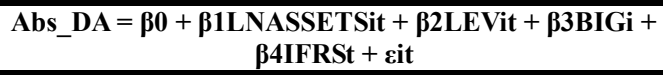 } \\
\hline & $\begin{array}{l}\text { Expected } \\
\text { Symbol }\end{array}$ & Coefficient & $\begin{array}{c}\mathrm{t} \\
\text { value }\end{array}$ & VIF \\
\hline Intercept & & $\begin{array}{c}0,265 \\
(0,001)\end{array}$ & 3,219 & \\
\hline LNASSETS & + & $\begin{array}{l}-0,006 \\
(0,167)\end{array}$ & $-1,385$ & 1,572 \\
\hline LEV & + & $\begin{array}{c}0,039 \\
(0,189)\end{array}$ & 1,316 & 1,101 \\
\hline BIG & - & $\begin{array}{c}0,005 \\
(0,723)\end{array}$ & 0,354 & 1,568 \\
\hline IFRS & - & $\begin{array}{c}-0,037 * * * \\
(0,001)\end{array}$ & $-3,233$ & 1,062 \\
\hline $\mathrm{N}$ & & 312 & & \\
\hline Adj $R^{2}$ & & 0,041 & & \\
\hline $\mathrm{F}$ & & $4,318 * * *$ & & \\
\hline
\end{tabular}

Source: processed data

***significant at the 0.01 level

Variable definition:

Abs_DA : The absolute value of discretionary accrual (proxy for AEM), measured by subtracting the total accrual from non-discretionary accrual

LNASSETS : The natural logarithm of company's assets (company Size), measured by the natural logarithm value of company's total asset

LEV : Company's leverage is total liabilities scaled by total assets

BIG : The auditor company (Dummy variable, BIG5 = 1; non-BIG5 = 0)

IFRS : The period before and after IFRS adoption (Dummy variable, period 2009-2011 = 0; period 2013-2015 = 1)

Table 4.5 presents the regression analysis result for the first regression model which measure the relationship between IFRS and AEM proxied by absolute discretionary accruals. Based on the table, the finding reveals that the independent variable IFRS shows a significantly negative coefficient -0.037 to the dependent variable AEM proxied by Abs_DA. It indicates that the adoption of IFRS reduce the AEM about 4 percent. Therefore, the first hypothesis: "After the adoption of IFRS, the magnitude of accrual earnings management in Indonesia companies decrease" is accepted.

Meanwhile, for all control variables are not significant towards AEM in this model. It is proved based on the regression results that the control variables LNASSETS, LEV, and BIG show the significant value greater than the 0.01 confidence level. It means that all control variables are not significant and doesn't have any influence to AEM.

$F$ value in this regression model is 4.318 and significant at 0.01 confidence level. It indicates that IFRS implementation has a signifiicant effect simultaneously towards accrual earnings management proxied by absolute discretionary accrual.

Table 4.6 performs the regression analysis result for the second model, the relationship between IFRS and REM.

TABLE 4.6

REGRESSION ANALYSIS

IFRS AND REM (SECOND MODEL)

\begin{tabular}{|c|c|c|c|c|}
\hline \multicolumn{5}{|c|}{ 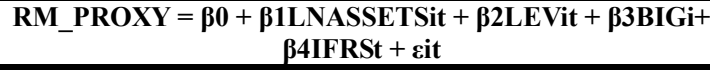 } \\
\hline & $\begin{array}{l}\text { Expected } \\
\text { Symbol }\end{array}$ & Coefficient & $\mathrm{t}$ value & VIF \\
\hline Intercept & & $\begin{array}{l}-1,340 \\
(0,000)\end{array}$ & $-4,386$ & \\
\hline LNASSETS & + & $\begin{array}{c}0,061^{* * *} \\
(0,000)\end{array}$ & 3,970 & 1,572 \\
\hline LEV & + & $\begin{array}{c}0,884 * * * \\
(0,000)\end{array}$ & 8,045 & 1,101 \\
\hline BIG & - & $\begin{array}{c}-0,364 * * * \\
(0,000)\end{array}$ & $-6,954$ & 1,568 \\
\hline IFRS & + & $\begin{array}{c}-0,194 * * * \\
(0,000)\end{array}$ & $-4,580$ & 1,062 \\
\hline $\mathrm{N}$ & & 312 & & \\
\hline Adj $R^{2}$ & & 0,356 & & \\
\hline $\mathrm{F}$ & & $43,899 * * *$ & & \\
\hline
\end{tabular}

236 | Jurnal Akuntansi, Ekonomi dan Manajemen Bisnis | Vol. 7 No.2, December 2019, 229-239 | E-ISSN: 2548-9836 
****significant at the 0.01 level

Variable definition:

RM_PROXY : A comprehensive measurement of REM, measured by combining three measurements of REM (-Ab_CFO + $\left.A b \_P R O D-A b \_D I S E X P\right)$

LNASSETS : The natural logarithm of company's assets (company Size), measured by the natural logarithm value of company's total asset

LEV : Company's leverage is total liabilities scaled by total assets BIG : The auditor company (Dummy variable, BIG5 = 1; non-BIG5 = 0)

IFRS : The period before and after IFRS adoption (Dummy variable, period 2009-2011 = 0; period 2013-2015 = 1)

Based on the table 4.6, the finding proves that the independent variable IFRS show a significantly negative coefficient -0.194 to the dependent variable REM. It indicates that the adoption of IFRS reduce the REM proxied by RM_PROXY about 19 percent. Therefore, the second hypothesis: "After the adoption of IFRS, the magnitude of real earnings management in Indonesia companies increase" is rejected. It is different with the previous findings which found that REM practices increase after the IFRS adoption because the management want to avoid the regulator and auditor detection by switching into the different form of AEM, namely REM.

Moreover, all the control variables in this regression model are significant at 0.01 confidence level. It shows that there is an effect between the control variables and the dependent variable RM_PROXY. LNASSETS and LEV show a significantly positive relationship with RM_PROXY. It means that the larger the company and the more levered are more prone to perform in REM. Meanwhile, the control variable BIG perform a significantly negative relationship towards RM_PROXY. It verifies that the bigger audit company hired by the company, the lower REM is performed by the management.

$F$ value in this regression model is 43.899 and significant at 0.01 confidence level. It reveals that the
IFRS implementation has a signifiicant impact simultaneously towards real earnings management.

\section{Analysis \\ IFRS and AEM}

Based on the first hypothesis test examining the relationship between IFRS and accrual earnings management proxied by the absolute discretionary accrual (Abs_DA), IFRS has a significantly negative effect to the accrual earnings management in the manufacturing companies in Indonesia. It proves that after the IFRS implementation in Indonesia, the existence of AEM is decrease. The negative sign of the independent variable IFRS verifies that after the adoption of international accounting standards, the company management performed lower accrual earnings management in Indonesia. The results are also supported by Paired t test result that shows a significantly downward in accrual earnings management in the period after the IFRS adoption. Meanwhile, in this model, all control variables are not significant towards accrual earnings management. It means that there is no influence of control variables to the dependent variable, AEM.

The result conveys that IFRS adoption leads to the enhancement of accounting information quality proved by lower accrual earnings management. This result also verifies that the more stringent the accounting standards is applied, the lower the accrual earnings management is performed by company management. Since, IFRS adoption give pressure on the company management to report truthfully the real company's performance. This findings is matching with the evidences found by [N]; [S]; [I]; [E].

\section{IFRS and REM}

Based on the second hypothesis test results, the independent variable IFRS exhibits the significantly negative effect to the dependent variable real earnings management is proxied by RM_PROXY. It indicates that the IFRS adoption decreases the real earnings management practice performed by 237 | Jurnal Akuntansi, Ekonomi dan Manajemen Bisnis | Vol. 7 No.2, December 2019, 229-239 | E-ISSN: 2548-9836 
company management. The negative sign of IFRS related to the real earnings management shows that the implementation of international accounting standard able to reduce real earnings management practice. This result conveys that IFRS able to limit the management practice in manipulating earnings through the other form of AEM, namely REM. The results of Paired t test also support this finding, in which REM decline in the period post-IFRS implementation. This finding is matching with the research findings of [G]; [T]; and [R].

The control variables are significant to the real earnings management in this regression model. LNASSETS and LEV have the significantly positive effect to the dependent variable of real earnings management. LNASSETS describes the company'size, while LEV describes the company's leverage ratio. It proves that the larger the company size and the more levered, then the larger REM is performed by the company management. Since, the larger the company size, it is assumed that the company has more moivation to manage the earnings due to the investor and stakeholders expectations about the company's performance.

Meanwhile, BIG that describes the auditor company (BIG5 and non-BIG5) presents a significantly negative effect towards RM_PROXY. It describes that the bigger the audit company, the lower the REM is performed by management. Since, it is assumed that the BIG 5 audit company have auditors that can detect the real earnings management practice in the company. Therefore, it can limit the REM practice in the company.

\section{Conclusion}

This study has two regression models that measure whether IFRS adoption has an effect towards AEM and REM in the manufacturing companies in Indonesia. These models is measured by regression analysis. Based on the result, it can be concluded that:
1. The IFRS adoption in Indonesia companies decreases the accrual earnings management practice. Since, the adoption of tighter international accounting standards can reduce the AEM practice performed by the company management.

2. The IFRS adoption in Indonesia companies decreases the real earnings management. Since, the adoption IFRS can limit the management's behavior to manipulate earnings through the different form of AEM, namely REM.

\section{References}

A. Aprilicia, V. (2014). Road Map International Financial Reporting Standard (IFRS) dan Implementasinya di Indonesia. Jurnal JIBEKA. Vol. 8. No. 1. pp. 60-64.

B. Aubert, F. and Grudnitski, G. (2012). Analysts' estimates What They Could be Telling Us about the Impact of IFRS on Earnings Manipulation in Europe. Review of Accounting and Finance. Vol. 11. No. 1. pp. 53-72.

C. Barth, M.E. et al. (2008). International Accounting Standards and Accounting Quality. Journal of Accounting Research. Vol. 46. No.3. pp.467-498.

D. Belkoui, Ahmed. (2001). Teori Akuntansi. Jakarta. Salemba Empat.

E. Burgstahler, D. et al. (2006). The Importance of Reporting Incentives: Earnings Management in European Private and Public Companys. The Accounting Review. Vol. 81. No. 5. pp. 983-1016.

F. Cahyonowati, N. and Ratmono, D. (2012). Adopsi IFRS dan Relevansi Nilai Informasi Akuntansi. Jurnal Akuntansi dan Keuangan. Vol. 14. No. 2. pp. 105-115.

G. Cheng, W. (2015). Trade-off Effect between Accrual Based Earnings Management and Real Earnings Management after the Adoption of 
Mandatory IFRS. (Unpublished Thesis). University of Amsterdam.

H. Cohen, D. A. and Zarowin, P. (2010). Accrual-based and Real Earnings Management Activities around Seasons Equity Offerings. Journal of Accounting and Economics. Vol. 50. pp. 2-19.

I. Ferentinou, A.C and Anagnostopoulou, S.C. (2014). Accrual-Based and Real Earnings Management Before and After IFRS Adoption. Journal of Applied Accounting Research. Vol.17. No.1. pp. 2-23.

J. Gumanti, T. A. (2004). Earnings Management: Suatu Telaah Pustaka. Jurnal Akuntansi dan Keuangan. Vol. 2. No. 2. pp. 104-115.

K. Ipino, E. and Parbonetti. A (2011). Mandatory IFRS Adoption: The Trade-Off between Accrual and Real-Based Earnings Management. Working Paper, SSRN. September.

L. Ismail, et al. (2013). Earnings Quality and the Adoption of IFRS-Based Accounting Standards. Asian Review of Accounting. Vol. 21. No. 1. pp. 53-73.

M. Jones, J. (1991). Earnings Management during Import Relief Investigation. Journal of Accounting Research. Vol. 2. No. 2. pp. 193-228.

N. Nuraini, H. I. (2014). Kualitas Informasi Akuntansi Sebelum dan Sesudah Konvergensi IFRS di Indonesia. (Unpublished Thesis). Gadjah Mada University: Yogyakarta.

O. Purwanti, Dyah. (2016). Real Activities Manipulation (RAM) and Accrual Based Earning Management Pre and Post IFRS Adoption in Indonesia. Atlantis Press. Vol. 15. pp. 96-99.

P. Roychowdhury, S. (2006). Earnings Management through Real Activities Manipulation. Journal of Accounting and Economics. Vol. 42. No. 3. pp. 335-370.
Q. Schipper, K. (1989). Commentary on Earnings Management. Accounting Horizons. Vol. 3. No. 4. pp. 91-102.

R. Senjani, Y. Putri. (2013). Manajemen Laba Akrual dan Riil Sebelum dan Setelah Adopsi Wajib IFRS di Uni Eropa. Jurnal Etikomomi. Vol. 12. No. 1. pp. 61-76.

S. Soderstrom, N. S and Sun, K. J. (2007). IFRS Adoption and Accounting Quality: A Review. European Accounting Review. Vol. 16. No. 14. pp. 675-702.

T. Utami, Ni Made P. et al. (2016). Manajemen Laba Berbasis Akrual dan Riil Sebelum dan Setelah Konvergensi IFRS Pada Perusahaan Manufaktur Terdaftar di BEI. Jurnal InFestasi. Vol. 12. No.1. pp. 36-54.

U. Watt, R. L. and Zimmerman, J. L. (1990). Positive Accounting Theory: A Ten Year Perspective. The Accounting Review. Vol. 65. No. 1. pp. 131-156.

V. Xu, R.Z. et al. (2007). Review of Real Earnings Management Literature. Journal of Accounting Literature. Vol. 26. pp. 195-228.

W. Zang, A. Y. (2012). Evidence on the Trade-off between Real Activities Manipulation and Accrual-Based Earnings Management. The Accounting Review. Vol. 87. No. 2. pp. 675-703. 